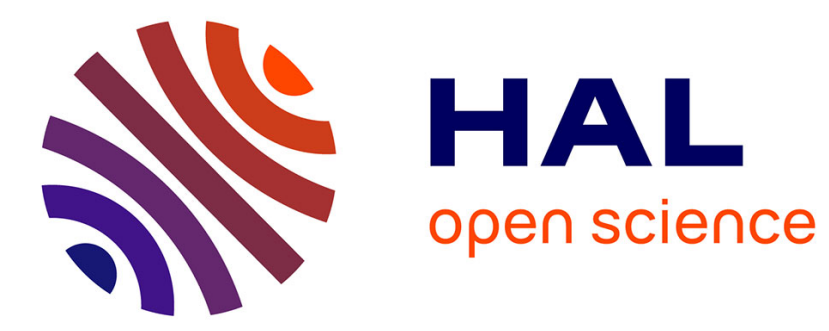

\title{
Vaporization and condensation in the Al4C3-SiC system
}

Hoang-Long Le-Tran, Eirini Sarigiannidou, Isabelle Gelard, Didier Chaussende

\section{To cite this version:}

Hoang-Long Le-Tran, Eirini Sarigiannidou, Isabelle Gelard, Didier Chaussende. Vaporization and condensation in the Al4C3-SiC system. Journal of the European Ceramic Society, 2017, 37 (15), pp.4475 - 4482. 10.1016/j.jeurceramsoc.2017.05.038 . hal-01620934

\section{HAL Id: hal-01620934 \\ https://hal.science/hal-01620934}

Submitted on 15 May 2021

HAL is a multi-disciplinary open access archive for the deposit and dissemination of scientific research documents, whether they are published or not. The documents may come from teaching and research institutions in France or abroad, or from public or private research centers.
L'archive ouverte pluridisciplinaire HAL, est destinée au dépôt et à la diffusion de documents scientifiques de niveau recherche, publiés ou non, émanant des établissements d'enseignement et de recherche français ou étrangers, des laboratoires publics ou privés. 


\title{
Vaporization and condensation in the $\mathrm{Al}_{4} \mathrm{C}_{3}-\mathrm{SiC}$ system
}

\author{
Hoang-Long Le-Tran, Eirini Sarigiannidou, Isabelle Gélard, Didier \\ Chaussende*
}

Univ. Grenoble Alpes, CNRS, Grenoble INP ${ }^{1}$, LMGP, F-38000 Grenoble, France

LMGP, Grenoble INP-Minatec, 3 parvis Louis Néel

CS 50257, 38016 Grenoble cedex 1, France

* E-mail: didier.chaussende@grenoble-inp.fr

\begin{abstract}
$\mathrm{Al}_{4} \mathrm{SiC}_{4}$ is a refractory ceramic with a reported band gap of about $2.5 \mathrm{eV}$, making it an interesting semiconductor material for various applications in the field of energy. However, the synthesis of $\mathrm{Al}_{4} \mathrm{SiC}_{4}$ single crystals has so far not been investigated. In this study, the sublimation growth method is explored as a potential route for getting high quality single crystals. Combining a thermodynamic analysis with an extensive experimental approach, the vaporization and condensation phenomena in the $\mathrm{Al}_{4} \mathrm{C}_{3}-\mathrm{SiC}$ system are described. Experimental conditions, such as initial composition, baking temperature and temperature gradient, are investigated and demonstrated regarding the crystallization of $\mathrm{Al}_{4} \mathrm{SiC}_{4}$. From the results obtained, a condensed phase diagram at equilibrium is established for the molar fraction $\mathrm{X}_{\mathrm{Al} 4 \mathrm{C} 3 /(\mathrm{Al} 4 \mathrm{C} 3+\mathrm{SiC})}<0.5$, which corresponds to the suitable condition for the $\mathrm{Al}_{4} \mathrm{SiC}_{4}$ condensation. Indeed, $\mathrm{Al}_{4} \mathrm{SiC}_{4}$ single phase could be experimentally condensed either by selfnucleation or as oriented film on $\mathrm{SiC}$ substrates.
\end{abstract}

\section{Introduction}

The Al-C-Si chemical system contains a family of aluminum-silicon ternary carbides that can be identified by the general formula $\left(\mathrm{Al}_{4} \mathrm{C}_{3}\right)_{\mathrm{x}}(\mathrm{SiC})_{\mathrm{y}}$. The first mention of such a compound appeared in a letter issued in 1961 by Barczak, who briefly reported on the synthesis of $\mathrm{Al}_{4} \mathrm{SiC}_{4}$ and the corresponding $\mathrm{X}$-ray diffraction data of two of its polymorphs, namely the $\alpha$ - and $\beta$-phases [1]. Thoroughly reconsidered by Schoennahl et al., the basic knowledge on $\mathrm{Al}_{4} \mathrm{SiC}_{4}$ was refined [2]. The authors detailed the possibility to synthesize small $\mathrm{Al}_{4} \mathrm{SiC}_{4}$ crystals by firing at high temperature, either as an $\mathrm{Al}_{4} \mathrm{SiC}_{4}$ sintered body or a mixture of $\mathrm{Al}_{4} \mathrm{C}_{3}$ and $\mathrm{SiC}$ raw materials. They also pointed out the extremely narrow temperature window for getting crystals, of about $30^{\circ} \mathrm{C}$ between $1950^{\circ} \mathrm{C}$ and $1980^{\circ} \mathrm{C}$, conditions under which small yellowish transparent platelets were obtained. Recently, different synthesis routes have been explored, such as solid state reaction and carbo-thermal reduction [3, 4].

After these first investigations, $\mathrm{Al}_{4} \mathrm{SiC}_{4}$ has been extensively studied as a high-temperature structural material and thermal coating for high temperature applications [5-8]. It combines advantageously some interesting ceramic properties, such as high melting point $\left(2080^{\circ} \mathrm{C}\right)$, low density $\left(3.03 \mathrm{~g} / \mathrm{cm}^{3}\right)$ and excellent oxidation and corrosion resistance. It is only recently that its electronic structure has been investigated theoretically through ab initio calculations, predicting semiconducting properties with an indirect bandgap of $1.05 \mathrm{eV}$ and a strong anisotropy of the transport properties due to a very high $\mathrm{c} / \mathrm{a}$ ratio in the lattice cell, close to 6.62 [9].

\footnotetext{
${ }^{1}$ Institute of Engineering Univ. Grenoble Alpes
} 
At first glance, the bandgap computed by Hussain et al. is not compatible with the transparency of the platelets reported by Schoennahl et al.. This discrepancy was the starting point of our investigation of $\mathrm{Al}_{4} \mathrm{SiC}_{4}$ materials. High quality single crystalline small platelets have been synthesized in order to measure the UV-Vis absorption spectrum of $\mathrm{Al}_{4} \mathrm{SiC}_{4}$. An optical bandgap of about $2.5 \mathrm{eV}$ [10] was found to be in good agreement with the one computed more recently by Pedesseau et al. [11]. According to the calculated band structure, $\mathrm{Al}_{4} \mathrm{SiC}_{4}$ exhibits both indirect and direct band gap energies of 2.5 and $3.2 \mathrm{eV}$, respectively. Slightly higher than the bandgap of $3 \mathrm{C}-\mathrm{SiC}$ (cubic polytype of $\mathrm{SiC}$ ), $\mathrm{Al}_{4} \mathrm{SiC}_{4}$ could be an interesting material for applications such as high temperature electronics, photovoltaic or photoelectrochemical water splitting. Semiconductor based applications usually require high quality, high purity crystals. The crystal growth process implemented must be also compatible with further upscaling, i.e. compatible with the current technologies, which is far from being straightforward for a refractory ternary carbide. In order to assess the applicability of the sublimation growth process, which has been developed for silicon carbide ingots production (see for instance [12, 13]), we investigate in the present paper, as a preamble, vaporization and condensation phenomena in the $\mathrm{Al}_{4} \mathrm{C}_{3}-\mathrm{SiC}$ binary system. Both thermodynamic calculations and experiments are confronted, in order to propose a vapor phase route for the synthesis of $\mathrm{Al}_{4} \mathrm{SiC}_{4}$ single crystals.

\section{Material and methods}

\subsection{Thermodynamic calculation}

Thermodynamic calculations of the ternary Al-Si-C were performed with the Factsage 6.0 package, using a set of coherent data from SGTE and SGPS, compiled from the refinement of the ternary Al-SiC system proposed by Gröbner et al. [14]. The different species considered in the present work are gathered in Table 1.

Table 1: Details of the chemical species considered in the present work, with the corresponding databases.

\begin{tabular}{|l|l|l|}
\hline & Chemical species & Database \\
\hline Vapor phase & $\begin{array}{l}\mathrm{Al}, \mathrm{Al}_{2}, \mathrm{AlC} \mathrm{Al}_{2} \mathrm{C}, \mathrm{AlC}_{2}, \mathrm{Al}_{2} \mathrm{C}_{2}, \mathrm{Si}_{2} \mathrm{Si}_{2}, \mathrm{Si}_{3}, \mathrm{SiC}, \mathrm{Si}_{2} \mathrm{C}, \\
\mathrm{SiC}_{2}, \mathrm{Si}_{2} \mathrm{C}_{2}, \mathrm{Si}_{3} \mathrm{C}, \mathrm{Si}_{3} \mathrm{C}_{2}, \mathrm{Si}_{4} \mathrm{C}, \mathrm{C}_{2}, \mathrm{C}_{3}, \mathrm{C}_{4}, \mathrm{C}_{5}, \mathrm{Ar}\end{array}$ & $\mathrm{SGPS}$ \\
\hline Liquid phase & $\mathrm{Al}, \mathrm{Si}, \mathrm{C}$ & SGTE \\
\hline Solutions & $\begin{array}{l}\text { Liquid alloys, Al-carbide with solubility for } \mathrm{Si}, \text { Hexagonal } \\
\text { closed packed phase with interstitial vacancy C }\end{array}$ & SGTE \\
\hline Solid phase & $\mathrm{Al}_{4} \mathrm{SiC}_{4}, \mathrm{Al}_{8} \mathrm{SiC}_{7}, \mathrm{SiC}, \mathrm{Al}_{4} \mathrm{C}_{3}, \mathrm{C}$ (graphite) & SGTE \\
\hline
\end{tabular}

Before discussing the gas phase composition, the validity of the compiled database has been assessed by computing an isothermal section at $1800^{\circ} \mathrm{C}$ and the pseudo-binary $\mathrm{Al}_{4} \mathrm{C}_{3}-\mathrm{SiC}$ section. The calculations were found in perfect agreement with the experimental works of Oden et al. [15]. The pseudo-binary section is characterized by the existence of two ternary carbides $\mathrm{Al}_{4} \mathrm{SiC}_{4}$ (also denoted as $\mathrm{Al}_{4} \mathrm{C}_{3} \mathrm{SiC}$ or $\mathrm{AS}$ ) and $\mathrm{Al}_{8} \mathrm{SiC}_{7}$ (also referred as $\left(\mathrm{Al}_{4} \mathrm{C}_{3}\right)_{2} \mathrm{SiC}$ or $2 \mathrm{AS}$ ). The first one would exhibit a congruent melting at about $2080^{\circ} \mathrm{C}$ and the second one a peritectic decomposition at $2085^{\circ} \mathrm{C}$.

The calculations have been conducted at constant volume for a temperature varying from 1500 to $2200^{\circ} \mathrm{C}$. The vapor phase is assumed to behave as a perfect gas. As initial conditions, we set a mixture of $\mathrm{SiC}$ and $\mathrm{Al}_{4} \mathrm{C}_{3}$ with various compositions, an argon atmosphere and an excess of solid carbon. These conditions have been selected because they are close to the experimental ones which are presented in the next section. To simulate the sublimation growth process, i.e. a growth cavity submitted to a 
temperature gradient, we used the following procedure: first, the equilibrium vapor phase composition is calculated at a given temperature ( $\mathrm{T}_{\text {POWDER }}$ which is the hot point) for a set of initial conditions. Then, all the gaseous phases are selected and injected as input conditions in a second calculation, at a lower temperature $\left(\mathrm{T}_{\mathrm{SEED}}\right)$. With such an approach, it is possible to describe on a pure thermodynamic footing, the nature and composition of the phases condensing at the seed side, which is the "cold point".

\subsection{Experiments}

Experiments have been performed in a high temperature furnace, developed for the seeded sublimation growth of SiC. General description of the growth cell is given in Figure 1(a). More details are available, for instance, in Ref. [16] together with a typical temperature distribution obtained by numerical simulation. Basically, it consists of an inductively heated graphite crucible placed in a watercooled quartz chamber. The whole crucible was made of graphite and insulated with graphite felts. Pressure and temperature were controlled during the process. Temperature was measured with a bichromatic optical pyrometer, from the back side of the crystallization area. Growth temperature was varied from 1900 to $2000^{\circ} \mathrm{C}$, and the growth pressure was fixed at 150 or 300 mbar using argon atmosphere. Source materials were composed of a mixture of high purity powders of $\mathrm{Al}_{4} \mathrm{C}_{3}$ (Alfa Aesar, 99+\% purity) and $\mathrm{SiC}$ (Sika tech E301) with a molar ratio $\mathrm{X}_{\mathrm{Al} 4 \mathrm{C} 3}$ defined as $\mathrm{X}_{\mathrm{Al} 4 \mathrm{C} 3}=\mathrm{nAl}_{4} \mathrm{C}_{3} /\left(\mathrm{nAl}_{4} \mathrm{C}_{3}+\mathrm{nSiC}\right) .4^{\circ}$ off-axis (to $<11-20>$ ) $4 \mathrm{H}-\mathrm{SiC}$ wafers with a chemo-mechanical polished silicon or carbon face were used as seed substrates. SiC substrates were stuck at the top of the crystallization area using graphite glue.

Reactor was manually heated up with a constant power until $1000^{\circ} \mathrm{C}$, the detecting range temperature of the used pyrometer. Afterwards, the heating rate was fixed at $30^{\circ} \mathrm{C} / \mathrm{min}$ until the growth temperature at high pressure $(\approx 800 \mathrm{mbar})$ in order to prevent the sublimation of raw materials. At the beginning of the annealing, the pressure was decreased to the growth pressure. During the growth, all parameters were stable. At the end of the annealing, the pressure was increased to 800 mbar to prevent any sublimation, and the reactor was cooled down by turning off the power. The schematic description of the process parameters is presented in Figure 1.

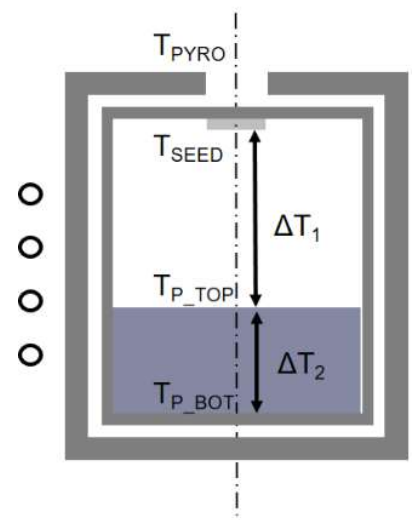

(a)

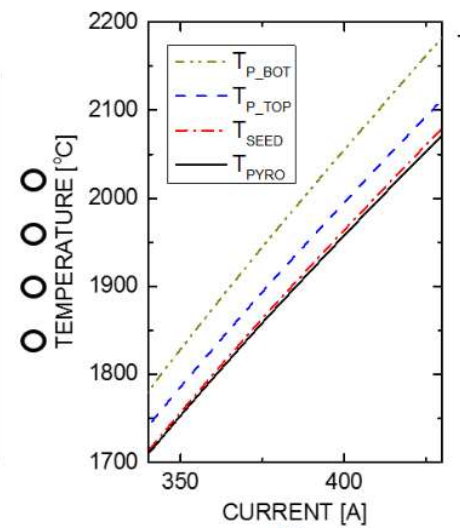

(b)

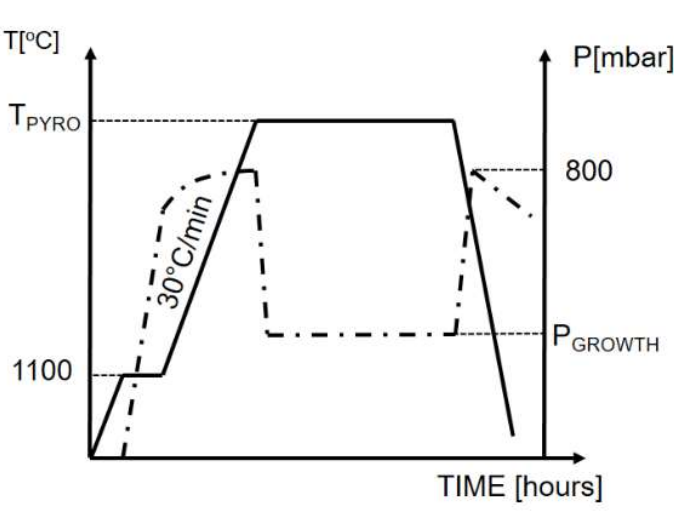

(c)

Figure 1: (a) Schematic drawing of the high temperature crucible. The distance between the powder surface and the seed was fixed at $5 \mathrm{~mm}$. In this geometry, two important temperature differences have been defined within the reaction cell, $\Delta T_{1}$ and $\Delta T_{2}$. (b) Computed temperatures taken at four different locations along the symmetry axis of the experimental geometry defined in (a) as a function of the electric current flowing through the induction coil, which is the input parameter for the calculations. (c) Temperature ( $T_{P Y R O}$, continuous line) and Pressure $(P$, dashed-dotted line) profiles used for the experiments. 
Inner temperature distribution of the reaction cell has been assessed by numerical simulation using the Finite Element Method (FEM) software, COMSOL Multiphysics. The simulation, coupling induction heating and heat transfers was performed in a two-dimensional axisymmetric geometry. The production and consumption of heat related to the chemical reactions in the powder and at the condensation area are neglected. We will mainly use hereafter four computed temperature points, as indicated in Figure 1(a) and plotted as a function of the input induction current in Figure 1(b) for a reference position of the induction coil with respect to the crucible. Two important temperature differences were defined as follow:

$$
\begin{aligned}
\Delta \mathrm{T}_{1} & =\mathrm{T}_{\mathrm{P}_{-} \mathrm{TOP}}-\mathrm{T}_{\mathrm{SEED}} \\
\Delta \mathrm{T}_{2} & =\mathrm{T}_{\mathrm{P}_{-} \text {BOT }}-\mathrm{T}_{\mathrm{P}_{-} \mathrm{TOP}}
\end{aligned}
$$

The adjustment of the temperature distribution in the seeded sublimation growth process of $\mathrm{SiC}$ has been extensively studied using numerical simulation. More specifically, the effect of the induction coil's position and the design of the heatsink on the temperature has been examined [17-19]. Based on a similar approach, and fixing the crucible design, we controlled the axial temperature gradients $\Delta \mathrm{T}_{1}$ and $\Delta \mathrm{T}_{2}$ by simply moving up and down the induction coil. As a rule, moving up the coil with respect to the reference position gives rise to a decrease of the temperature gradients. Conversely, by moving down the coil, the temperature gradients increase.

Phase analysis has been conducted by X-Ray Diffraction (XRD) using a Bruker D8 Advance diffractometer with the $\mathrm{Cu} \mathrm{K} \alpha 1$ radiation in the Bragg-Brentano configuration. Refinement using the Rietveld treatment has been carried out to analyze phases on a quantitative footing. For more local identification, such as, for instance, for a single grain, we used a Jobin Yvon/Horiba LabRam Raman spectrometer equipped with a liquid nitrogen cooled coupled charge device detector. The green laser excitation $(\lambda=514.5 \mathrm{~nm})$ was focused to a spot size in the range of $1 \mu \mathrm{m}^{2}$ on the sample. Raman spectra were calibrated by using a silicon single crystalline wafer at room temperature.

\section{Results and discussion}

\subsection{Thermochemistry of the gas-solid system}

Table 2 gives the computed equilibrium partial pressures of the different gaseous species at $2000^{\circ} \mathrm{C}$ for an initial composition of $\mathrm{X}_{\mathrm{Al} 4 \mathrm{C} 3}=0.5$. The partial pressures clearly spread over a large range of values, which are distributed on ten orders of magnitudes. Some species can thus be neglected. The system can be described accurately by considering only 7 species, namely $\mathrm{Al}(\mathrm{g}), \mathrm{Al}_{2}(\mathrm{~g}), \mathrm{AlC}_{2}(\mathrm{~g}), \mathrm{Al}_{2} \mathrm{C}_{2}(\mathrm{~g}), \mathrm{Si}(\mathrm{g})$, $\mathrm{C}_{2} \mathrm{Si}(\mathrm{g})$ and $\mathrm{CSi}_{2}(\mathrm{~g})$. The evolution of the partial pressures of these species as a function of temperature is plotted in Figure 2(a). The corresponding atomic ratios $\mathrm{C} / \mathrm{Si}$ and $\mathrm{Al} / \mathrm{Si}$ in the gas phase are plotted in Figure 2(b). On this latter figure, we added two grey, thick horizontal lines which represent the stoichiometry of the two solid compounds $\mathrm{Al}_{4} \mathrm{SiC}_{4}$ and $\mathrm{Al}_{8} \mathrm{SiC}_{7}$, encountered in the pseudo-binary section. These two ternary carbides have atomic ratios of $\mathrm{Al} / \mathrm{Si}=\mathrm{C} / \mathrm{Si}=4$ for $\mathrm{Al}_{4} \mathrm{SiC}_{4}$, and $\mathrm{Al} / \mathrm{Si}=8$ and $\mathrm{C} / \mathrm{Si}=7$ for $\mathrm{Al}_{8} \mathrm{SiC}_{7}$.

Table 2: Equilibrium partial pressures of the different gaseous species computed from an initial mixture of $X_{A l 4 C 3}=0.5$ at $2000^{\circ} \mathrm{C}$.

\begin{tabular}{|l|l|l|l|l|l|l|l|l|l|}
\hline Species & $\mathrm{C}_{2}(\mathrm{~g})$ & $\mathrm{C}_{3}(\mathrm{~g})$ & $\mathrm{C}_{4}(\mathrm{~g})$ & $\mathrm{C}_{5}(\mathrm{~g})$ & $\mathrm{Al}(\mathrm{g})$ & $\mathrm{Al}_{2}(\mathrm{~g})$ & $\mathrm{AlC}_{(\mathrm{g})}$ & $\mathrm{AlC}_{2}(\mathrm{~g})$ & $\mathrm{Al}_{2} \mathrm{C}_{2}(\mathrm{~g})$ \\
\hline $\mathrm{p}_{i}[\mathrm{bar}]$ & $8.82 \mathrm{E}-10$ & $1.01 \mathrm{E}-8$ & $2.30 \mathrm{E}-12$ & $1.01 \mathrm{E}-11$ & 0.07 & $2.22 \mathrm{E}-4$ & $1.35 \mathrm{E}-7$ & $2.88 \mathrm{E}-6$ & $4.19 \mathrm{E}-4$ \\
\hline Species & $\mathrm{Si}_{2}(\mathrm{~g})$ & $\mathrm{Si}_{3}(\mathrm{~g})$ & $\mathrm{CS}(\mathrm{g})$ & $\mathrm{C}_{2} \mathrm{Si}(\mathrm{g})$ & $\mathrm{CSSi}_{2}(\mathrm{~g})$ & $\mathrm{C}_{2} \mathrm{Si}_{2}(\mathrm{~g})$ & $\mathrm{CS}_{3}(\mathrm{~g})$ & $\mathrm{C}_{2} \mathrm{Si}_{3}(\mathrm{~g})$ & $\mathrm{CSi}_{4}(\mathrm{~g})$ \\
\hline $\mathrm{p}_{i}[\mathrm{bar}]$ & $7.95 \mathrm{E}-7$ & $3.90 \mathrm{E}-8$ & $1.07 \mathrm{E}-8$ & $1.36 \mathrm{E}-5$ & $2.54 \mathrm{E}-5$ & $4.36 \mathrm{E}-7$ & $2.27 \mathrm{E}-7$ & $1.22 \mathrm{E}-7$ & $1.00 \mathrm{E}-10$ \\
\hline Species & $\mathrm{Si}(\mathrm{g})$ & & & & & & & & \\
\hline $\mathrm{p}_{i}[\mathrm{bar}]$ & $1.08 \mathrm{E}-4$ & & & & & & & & \\
\hline
\end{tabular}



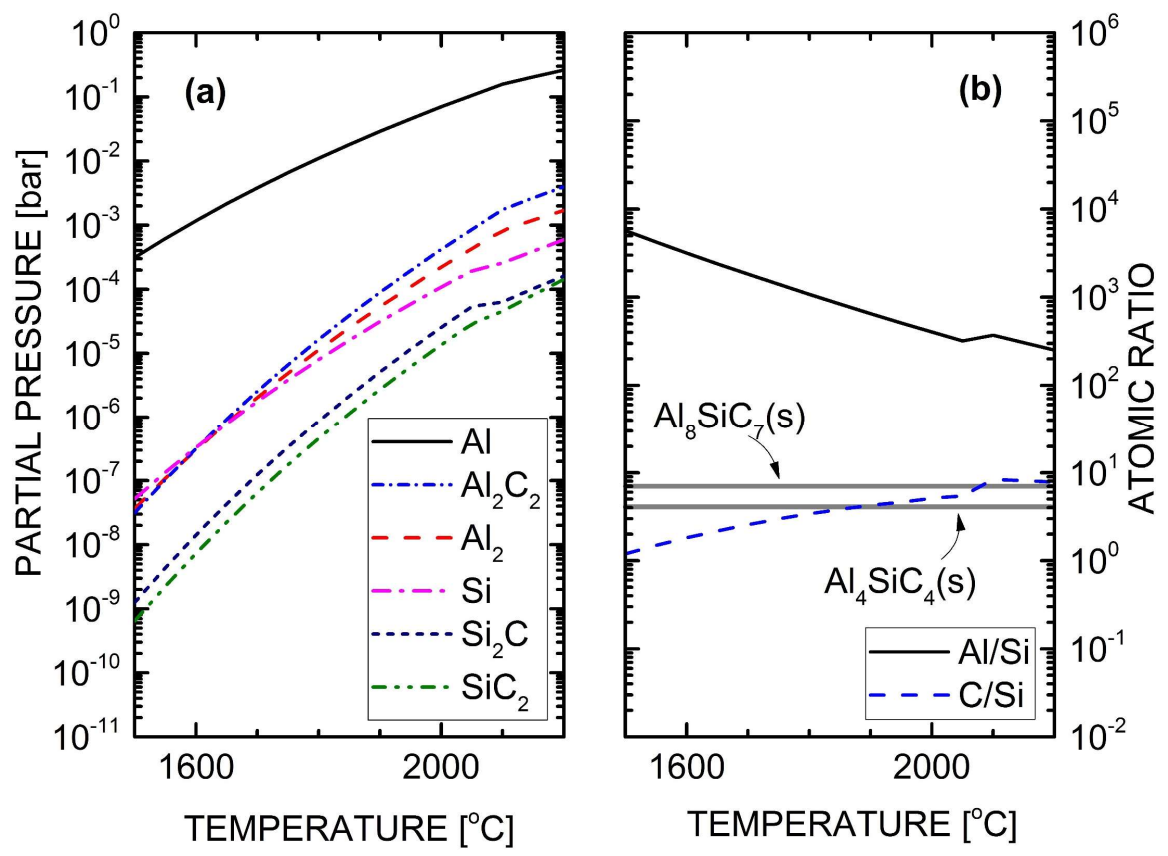

Figure 2: (a) Equilibrium partial pressures of the main vapor species as a function of temperature for an initial composition $X_{A l 4 C 3}=0.5$ of the source materials. (b) Corresponding C/Si and Al/Si atomic ratios in the gas phase as a function of temperature. Gray lines represent the stoichiometry of the two solid compounds $\mathrm{Al}_{4} \mathrm{SiC}_{4}$ and $\mathrm{Al}_{8} \mathrm{SiC}_{7}$.

As expected, vaporization of $\mathrm{Al}_{4} \mathrm{C}_{3}-\mathrm{SiC}$ ceramics strongly increases with temperature. The vapor composition is characterized by the huge predominance of $\mathrm{Al}(\mathrm{g})$, representing more than $95 \%$ of the molar fraction. The most abundant carbon containing species is $\mathrm{Al}_{2} \mathrm{C}_{2}(\mathrm{~g})$ at any temperature. Similarly to aluminum, the dominant silicon gaseous species is atomic silicon $\mathrm{Si}(\mathrm{g}) . \mathrm{Si}_{2} \mathrm{C}(\mathrm{g})$ and $\mathrm{SiC}_{2}(\mathrm{~g})$ which are the common vaporization species of $\mathrm{SiC}$, are about one order of magnitude lower than the main $\mathrm{C}$ and Si-containing species. A small discontinuity appears around $2080^{\circ} \mathrm{C}$; it corresponds to the melting point of $\mathrm{Al}_{4} \mathrm{SiC}_{4}$. The atomic ratios in Figure 2(b) give a good description of the gas phase stoichiometry, especially the very strong deviation from the solid phase stoichiometry. Basically, when the temperature increases, the $\mathrm{Al} / \mathrm{Si}$ ratio decreases while the $\mathrm{C} / \mathrm{Si}$ ratio increases. The $\mathrm{Al} / \mathrm{Si}$ ratio is much higher than the stoichiometry of the solid phases at any temperature, but get closer with increasing temperature. It is rather different for the $\mathrm{C} / \mathrm{Si}$ ratio which matches the solid phase stoichiometry for specific temperatures. For instance, the gas phase shows the same $\mathrm{C} / \mathrm{Si}$ ratio as $\mathrm{Al}_{4} \mathrm{SiC}_{4}$ and $\mathrm{Al}_{8} \mathrm{SiC}_{7}$ at about $1880^{\circ} \mathrm{C}$ and $2100^{\circ} \mathrm{C}$ respectively, for the starting composition used.

The behavior of the gas phase composition as a function of the initial composition of the source materials is also interesting. Obviously, the apparent activity of $\mathrm{Si}$ in the gas phase changes from the one in equilibrium with pure $\mathrm{SiC}(\mathrm{s})$ to zero, while shifting the composition from pure $\mathrm{SiC}(\mathrm{s})$ to pure $\mathrm{Al}_{4} \mathrm{C}_{3}(\mathrm{~s})$ along the pseudo-binary section. Conversely, the apparent activity of $\mathrm{Al}$ increases from zero for pure $\mathrm{SiC}(\mathrm{s})$ to the equilibrium one for pure $\mathrm{Al}_{4} \mathrm{C}_{3}(\mathrm{~s})$. The description of the gas phase composition as a function of $\mathrm{X}_{\mathrm{A} 14 \mathrm{C} 3}$ molar ratio is given in Figure 3, for a temperature fixed at $1900^{\circ} \mathrm{C}$. At any composition of the raw materials in the pseudo-binary section, the vapor phase is characterized by a strong excess of $\mathrm{Al}$. However, the $\mathrm{C} / \mathrm{Si}$ in the gas phase is almost matching the one of $\mathrm{Al}_{4} \mathrm{SiC}_{4}$ for an initial mole fraction $<0.5$ and the one of $\mathrm{Al}_{8} \mathrm{SiC}_{7}$ for an initial mole fraction comprised between 0.5 and 0.63 . 


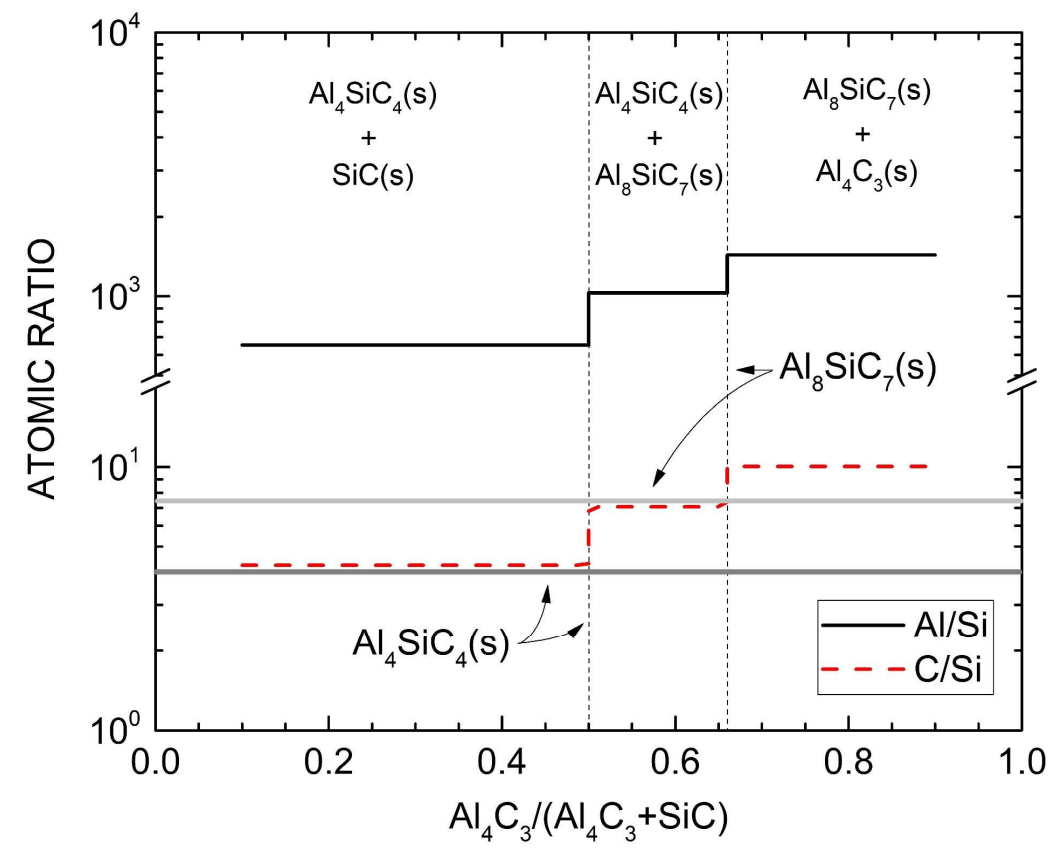

Figure 3: Al/Si and C/Si atomic ratios in the gas phase as a function of $X_{A l 4 C 3}$ in the starting materials. Baking temperature was set at $1900^{\circ} \mathrm{C}$.

To simulate the nature of the deposit forming at the crystallization area (cold point) from the gaseous species coming from the vaporization area (hot point), we implemented the procedure described in section 2.2. Obviously, as reaction kinetics and mass transport are not considered, the results presented here are only of a qualitative nature. From the equilibrium gas phase composition calculated at $2000^{\circ} \mathrm{C}$ for the molar fraction $\mathrm{X}_{\mathrm{A} 14 \mathrm{C} 3}=0.4$, we computed the net amounts of solid compounds formed (Figure $4(\mathrm{a})$ ) as a function of $\Delta \mathrm{T}$ which is defined by $\mathrm{T}_{\text {SOURCE }}-\mathrm{T}_{\text {SEED }}$. The corresponding gas phase composition $(\mathrm{Al} / \mathrm{Si}$ and $\mathrm{C} / \mathrm{Si}$ ) in the crystallization zone is also plotted, in Figure 4(b). Starting from the same temperature of the source, or differently said, the same flux of species vaporized from the source, we can identify different compounds condensing at the crystallization area, depending on the temperature difference. $\mathrm{Al}_{4} \mathrm{SiC}_{4}$ condenses for small temperature differences $(\Delta \mathrm{T})$, typically smaller than $40^{\circ} \mathrm{C}$. Between 40 and $80^{\circ} \mathrm{C}, \mathrm{Al}_{8} \mathrm{SiC}_{7}$ dominates. Note that at $40 \pm 10^{\circ} \mathrm{C}$, the crystallization conditions are characterized by the coexistence of the two ternary carbides. Then, for $\Delta \mathrm{T}$ higher than $80^{\circ} \mathrm{C}, \mathrm{Al}_{4} \mathrm{C}_{3}$ alone condenses. The composition of the gas phase directly correlates with the different condensed solid compounds. The crystallization of $\mathrm{Al}_{4} \mathrm{SiC}_{4}$ requires a $\mathrm{C} / \mathrm{Si}$ ratio close to the one in the solid and a minimum $\mathrm{Al} / \mathrm{Si}$; such conditions are found at low temperature gradient. Then, by increasing the temperature gradient, both $\mathrm{Al} / \mathrm{Si}$ and $\mathrm{C} / \mathrm{Si}$ in the gas phase increase. It is thus not surprising that the ternary compound with higher $\mathrm{Al}_{4} \mathrm{C}_{3}$ content occurs. Finally, when the $\mathrm{Al} / \mathrm{Si}$ and $\mathrm{C} / \mathrm{Si}$ get too high, the silicon content of the gas phase becomes negligible and only $\mathrm{Al}_{4} \mathrm{C}_{3}$ is formed.

Using the same procedure as the one used in Figure 4(a), it is possible to predict the nature of the solid phases as a function of both $\mathrm{T}_{\text {SOURCE }}$ and $\mathrm{T}_{\mathrm{SEED}}$. A phase diagram can thus be drawn, as illustrated in Figure 5. 

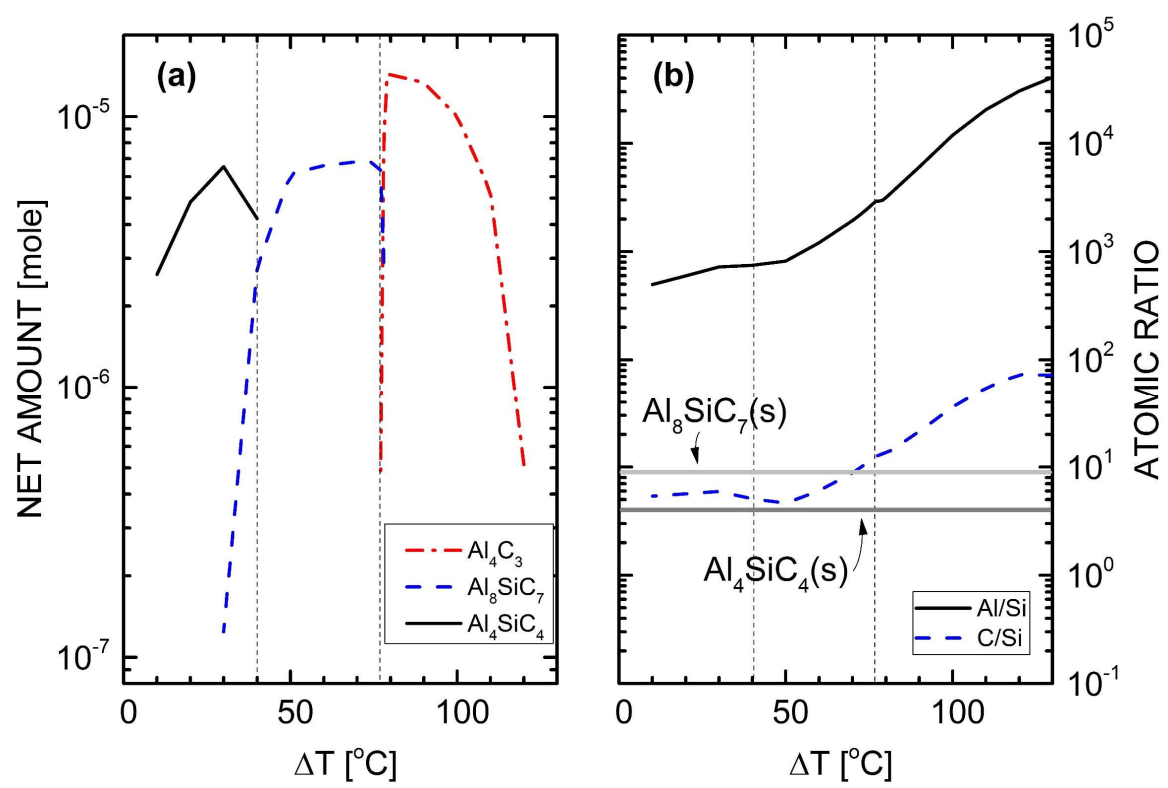

Figure 4: a) The net amounts of solid compounds formed as a function of $\Delta T$. b) Corresponding gas phase composition in the crystallization zone (seed). The gas phase composition at the vaporization zone (source) has been calculated at $2000^{\circ} \mathrm{C}$ for an initial source composition $X_{A l 4 C 3}=0.4$. $\Delta$ T is defined by $T_{\text {SOURCE }}-T_{\text {SEED }}$. Vertical dotted lines have been added as a guide for separating the different deposition conditions.

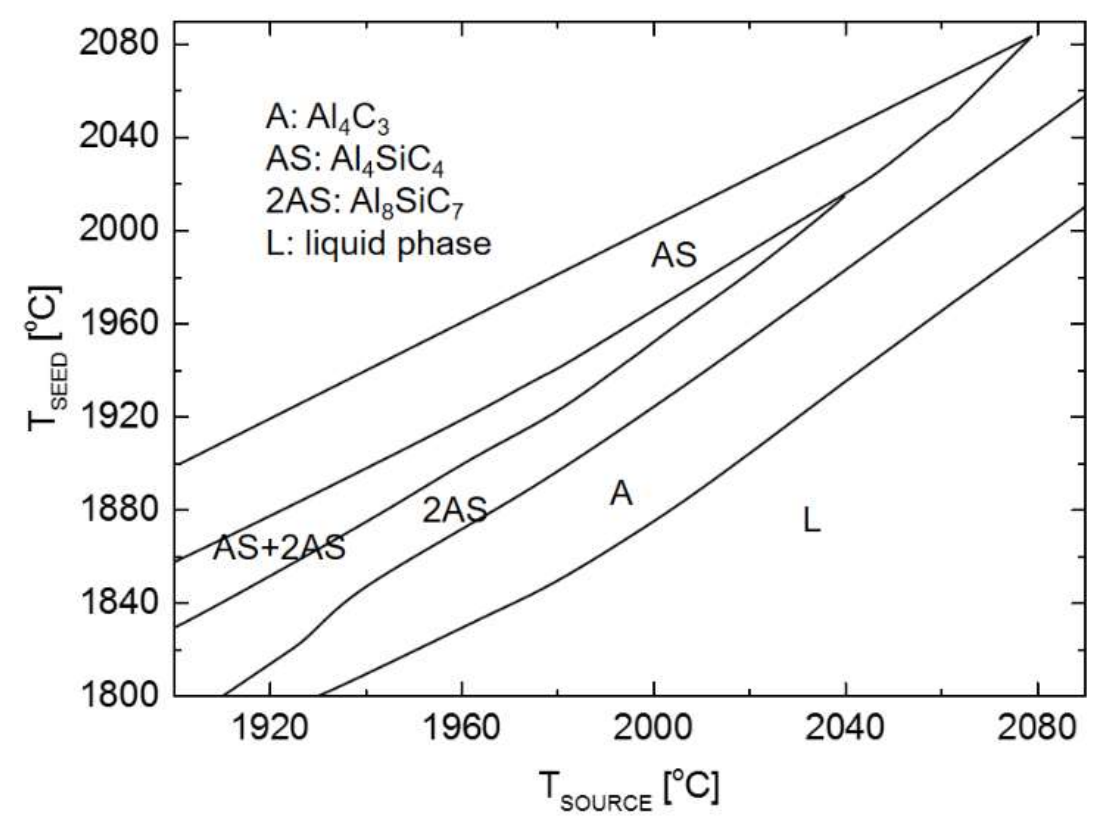

Figure 5: Diagram of the solid phases condensed from the vapor phase at equilibrium as a function of the temperatures of the seed and the source, for an initial composition $X_{A l 4 C 3}<0.5$. The diagram was calculated with a powder temperature higher than $1900^{\circ} \mathrm{C}$.

A comparison between calculations performed in homogeneous phase (without any solid allowed to be formed) and in heterogeneous phase gives a good estimate of the main gaseous species which contribute to the deposit. The net contribution represented in Figure 6(a) corresponds to the difference between the partial pressure of the different species calculated in homogeneous phase and the ones in 
heterogeneous phase. In order to weight the contribution of each gaseous components, we plotted in Figure 6(b) the relative contribution, defined as the ratio of the net contribution and the partial pressure from heterogeneous phase calculation. At low $\Delta \mathrm{T}$, condition under which the crystallization of $\mathrm{Al}_{4} \mathrm{SiC}_{4}$ occurs, $\mathrm{Al}_{2} \mathrm{C}_{2}(\mathrm{~g})$ brings the highest contribution to $\mathrm{Al}$ and $\mathrm{C}$. Atomic $\mathrm{Si}(\mathrm{g})$ is the most contributing species to Si condensation. Obviously, the contribution of these species increases with the temperature gradient. A very simple reaction can thus be drawn for the condensation of $\mathrm{Al}_{4} \mathrm{SiC}_{4}$ from the vapor phase:

$$
2 \mathrm{Al}_{2} \mathrm{C}_{2}(\mathrm{~g})+\mathrm{Si}(\mathrm{g}) \rightarrow \mathrm{Al}_{4} \mathrm{SiC}_{4}(\mathrm{~s})
$$

For a $\Delta \mathrm{T}$ higher than $40^{\circ} \mathrm{C}$, the net contribution of $\mathrm{Al}_{2} \mathrm{C}_{2}(\mathrm{~g})$ and $\mathrm{Si}(\mathrm{g})$ is quite stable. However, the contribution of monoatomic and polyatomic Aluminum molecules such as $\mathrm{Al}(\mathrm{g})$ and $\mathrm{Al}_{2}(\mathrm{~g})$ increase strongly with temperature gradient, leading to an $\mathrm{Al}$ enrichment of the solid phase. Concerning the relative contribution, $\mathrm{Al}_{2} \mathrm{C}_{2}(\mathrm{~g})$ and $\mathrm{Si}(\mathrm{g})$ are by far the most contributing species, about a few orders of magnitude higher than $\mathrm{Al}(\mathrm{g})$ and $\mathrm{Al}_{2}(\mathrm{~g})$. This means that $\mathrm{Al}_{2} \mathrm{C}_{2}(\mathrm{~g})$ and $\mathrm{Si}(\mathrm{g})$ are the "thermodynamically limiting" species for the condensation over all the conditions studied.
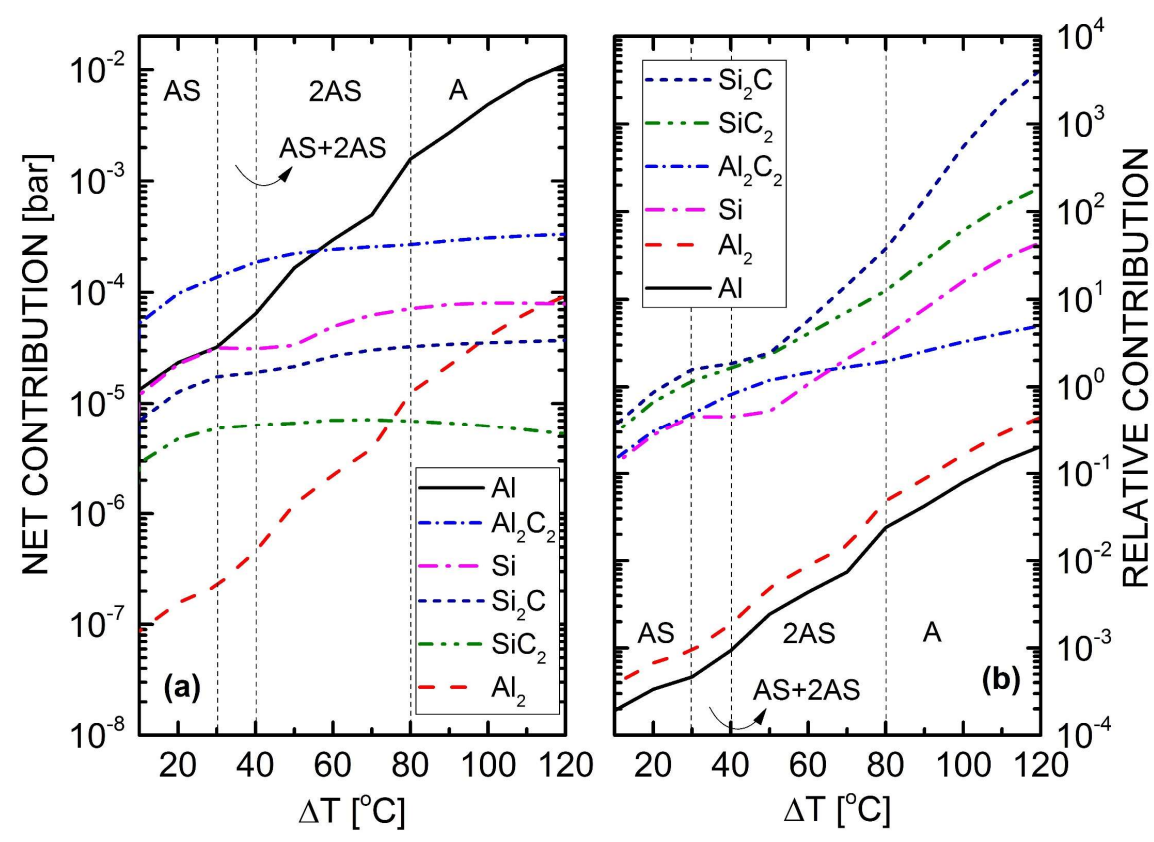

Figure 6: (a) Net contribution of the main vapor species (sublimated at $2000^{\circ} \mathrm{C}$ with pressure near 300 mbar) to the deposit as a function of the temperature gradient. (b) Relative contribution of the same species, defined by the ratio between the net contribution and the equilibrium partial pressure of the species, calculated in the heterogeneous case. Three condensed-phase zones are consecutively identified such as $\mathrm{Al}_{4} \mathrm{SiC}_{4}(\mathrm{AS}), \mathrm{Al}_{8} \mathrm{SiC}_{7}(2 \mathrm{AS})$ and $\mathrm{Al}_{4} C_{3}(\mathrm{~A})$ by increasing the temperature gradient.

\subsection{Experimental results and discussion}

\subsubsection{Powder evolution}

In order to investigate the evolution of powder as a function of time, experiments were performed at a temperature of $2000^{\circ} \mathrm{C}$ and a pressure of 300 mbar with a baking time varying from 20 min to $2 \mathrm{~h}$. A second set of experiments has been conducted at $1900^{\circ} \mathrm{C}, 150 \mathrm{mbar}$ with the same initial composition but for longer times. Thanks to the thermodynamic calculations, an initial composition $\mathrm{X}_{\mathrm{Al} 4 \mathrm{C} 3}<0.5$ has been chosen as the most suitable for the crystallization of $\mathrm{Al}_{4} \mathrm{SiC}_{4}$. Figure 7(a) is a camera picture of the 
section of the source material after baking an $\mathrm{Al}_{4} \mathrm{C}_{3}-\mathrm{SiC}$ mixture, having an initial molar composition $\mathrm{X}_{\mathrm{Al} 14 \mathrm{C} 3}=0.2$, during $2 \mathrm{~h}$ at $2000^{\circ} \mathrm{C}$. Three different layers can be clearly evidenced on the section, namely the bottom (3), medium (2) and top (1) layers. The initial level of the powder mixture is indicated by the black dashed line between layers (1) and (2). A backscattered electron (BSE) picture of each layer of the cross section has been added to Figure 7. For each stratum, a sample of powder has been extracted and grinded by ball milling. Qualitative (phase identification) and quantitative (atomic ratio of each phase) analyses have been performed using XRD measurements coupled with Rietveld refinements.

(1) The top layer (Figure 7b) is mainly composed of an entanglement of very thin, light-orange platelets. This layer was formed above the initial level of the powder and was thus only due to vaporization-condensation reactions in the open cavity. XRD analysis revealed a majority of $\mathrm{Al}_{4} \mathrm{SiC}_{4}$ and very small amounts of $\mathrm{SiC}, \mathrm{Al}$ and $\mathrm{Si}$. Small particles containing $\mathrm{Al}$ and $\mathrm{Si}$ are visible on the surface of the platelets in the SEM pictures. They look like solidified droplets. These minority phases could form during cooling down or could be residues coming from a cross-contamination during the separation of layers (1) and (2).

(2) The medium layer (Figure 7c) exhibits a higher density of solid with at least two contrasts of grey levels, suggesting the coexistence of several phases. No real platelet could be observed and the solid shows a granular texture. The phases identified by XRD are $\mathrm{Al}_{4} \mathrm{SiC}_{4}, \mathrm{SiC}, \mathrm{Al}$ and $\mathrm{Si}$, with the corresponding composition given in Table 3.

(3) The bottom layer (Figure 7d), with a dominant black color, consists of a high density of small grains having a contrast close to that of the graphite crucible. Indeed, this stratum is mostly composed of $\mathrm{SiC}(80 \mathrm{~mol} \%)$ and graphite $(19 \mathrm{~mol} \%)$ with a very small amount of $\mathrm{Al}_{4} \mathrm{SiC}_{4}(1$ mol\%). The graphitization front propagating from the edge of the grains to the center, it is not surprising to observe a black color (attributed to graphite with BSE) although XRD revealed a much higher SiC content, probably confined as core of the grains and not directly observable using BSE.

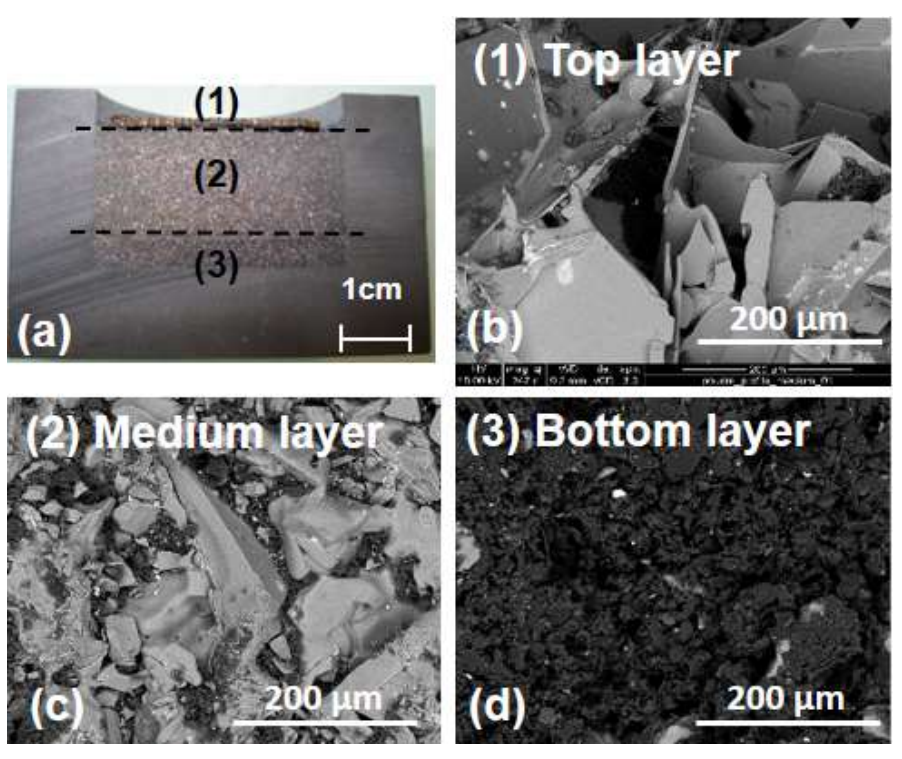



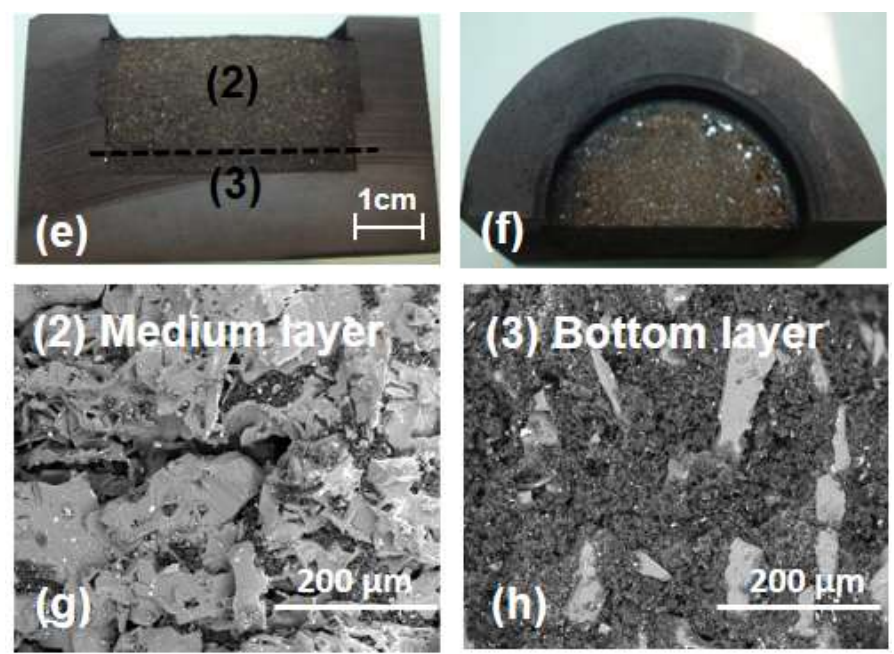

Figure 7: a) Cross-section of the powder load after experiment; the composition of raw materials is $X_{A l 4 C 3}=0.2$ and the baking conditions are $T=2000^{\circ} \mathrm{C}, P=300 \mathrm{mbar}$ and time $=2 \mathrm{~h}$. Three different layers, denoted as (1) top, (2) medium and (3) bottom layers can be identified. Corresponding backscattering electron (BSE) pictures are presented on picture $b, c$ and $d$ respectively. Pictures $e$ and $f$ are crosssection and top view pictures of a powder load baked $4 \mathrm{~h}$ at $1900^{\circ} \mathrm{C}$ and $150 \mathrm{mbar}$ with the same initial composition. In this case, only two different layers can be identified which are denoted as medium and bottom layer. The corresponding BSE pictures are presented on picture $g$ and $h$.

At $1900^{\circ} \mathrm{C}$ (Figure 7(e) to (h)), there is no evidence of the formation of the top layer (1) and the cross-section of the powder annealed during $4 \mathrm{~h}$ shows only layers (2) and (3). In this case, the layer (2) is composed of $\mathrm{Al}_{4} \mathrm{SiC}_{4}, \mathrm{SiC}$ and $\mathrm{C}$ without free $\mathrm{Al}$ or $\mathrm{Si}$.

In all cases, the composition of $\mathrm{Al}_{4} \mathrm{SiC}_{4}, \mathrm{Al}, \mathrm{SiC}$ and graphite (C) was tracked from the XRD analyses. The molar fractions of the medium layer (i.e. layer (3)) are gathered in Table 3.

Table 3: Molar fraction of each components, obtained by XRD Rietveld analyses of powder samples extracted from the medium layer (located in the middle of the crucible and close to the powder surface) for different experimental conditions.

\begin{tabular}{|c|c|c|c|c|c|}
\hline \multirow{2}{*}{ Experimental conditions } & \multicolumn{5}{|c|}{ Mole fraction } \\
\cline { 2 - 6 } & $\mathrm{Al}_{4} \mathrm{SiC}_{4}$ & $\mathrm{SiC}$ & $\mathrm{C}$ & $\mathrm{Si}$ & $\mathrm{Al}$ \\
\hline $2000^{\circ} \mathrm{C}, 300 \mathrm{mbar}, 20 \mathrm{~min}$ & 0.13 & 0.43 & 0.06 & 0.04 & 0.34 \\
\hline $2000^{\circ} \mathrm{C}, 300 \mathrm{mbar}, 60 \mathrm{~min}$ & 0.10 & 0.34 & 0.14 & 0.03 & 0.39 \\
\hline $2000^{\circ} \mathrm{C}, 300 \mathrm{mbar}, 120 \mathrm{~min}$ & 0.13 & 0.53 & 0.11 & 0.02 & 0.21 \\
\hline $1900^{\circ} \mathrm{C}, 150 \mathrm{mbar}, 120 \mathrm{~min}$ & 0.20 & 0.59 & 0.21 & & \\
\hline $1900^{\circ} \mathrm{C}, 150 \mathrm{mbar}, 240 \mathrm{~min}$ & 0.29 & 0.60 & 0.11 & & \\
\hline $1900^{\circ} \mathrm{C}, 150 \mathrm{mbar}, 360 \mathrm{~min}$ & 0.19 & 0.74 & 0.07 & & \\
\hline
\end{tabular}

To get an estimation of the mass fluxes coming from the two carbides, we measured the weight loss as a function of time for two different initial compositions, pure $\mathrm{SiC}\left(\mathrm{X}_{\mathrm{Al} 4 \mathrm{C} 3}=0\right)$ on the one hand and a mixture with $\mathrm{X}_{\mathrm{A} 14 \mathrm{C} 3}=0.2$ on the other hand. Results are gathered in Figure 8. The same total volume of powder and annealing conditions have been applied in order to keep a constant source-to-seed distance 
and an equivalent temperature distribution. Under such conditions, the vaporization rate of $\mathrm{SiC}$ is about $10 \mathrm{mg} / \mathrm{h}$ and the one of the mixture around two orders of magnitude higher. A dramatically increase of the vaporization rate demonstrates the dominant role of $\mathrm{Al}_{4} \mathrm{C}_{3}$ in the sublimation mass flux of the mixture. At lower temperature $\left(1900^{\circ} \mathrm{C}\right.$ and $\left.150 \mathrm{mbar}\right)$, the annealing time must be longer: $6 \mathrm{~h}$ of annealing are necessary to get almost the same weight loss than after $2 \mathrm{~h}$ at $2000^{\circ} \mathrm{C}$ and $300 \mathrm{mbar}$.

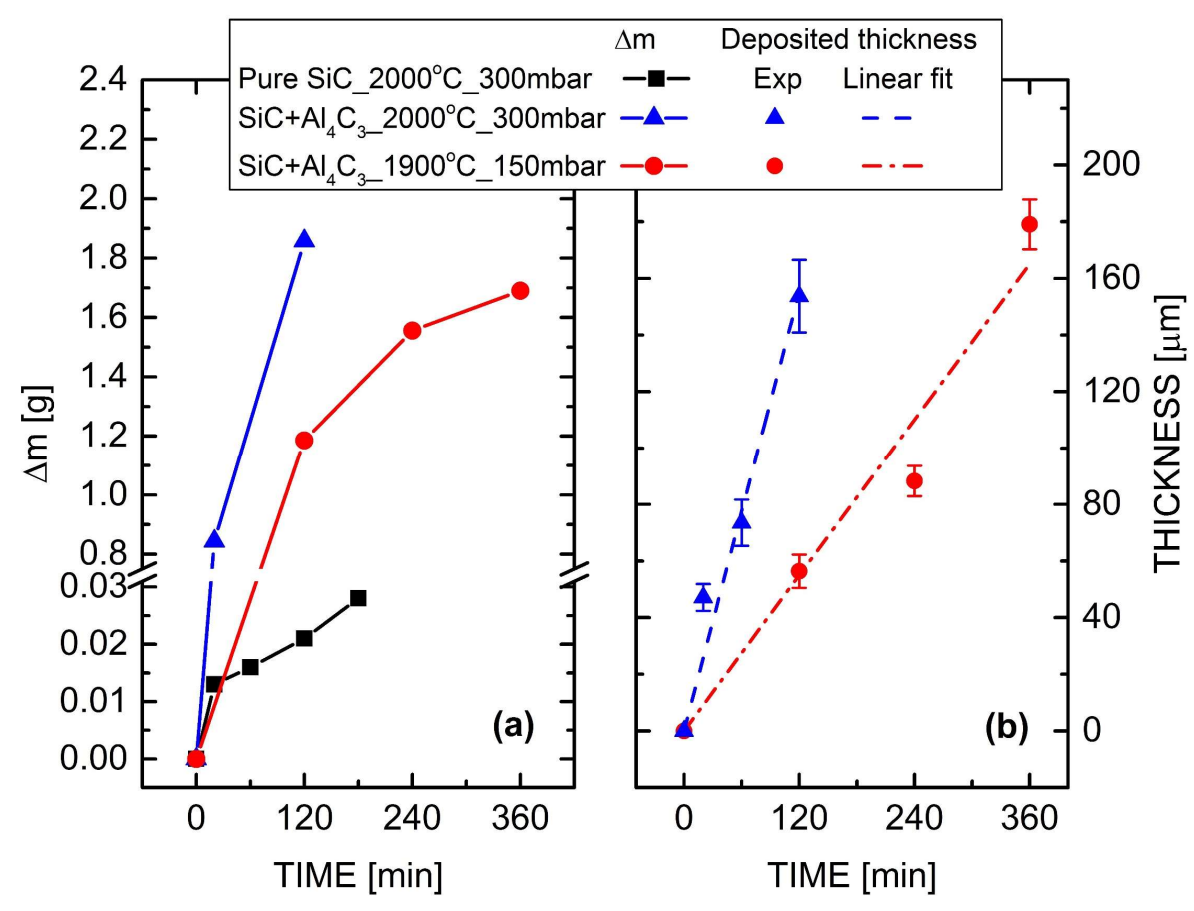

Figure 8: (a) Evolution of the weight loss of the powder as a function of time for two initial compositions: pure $\mathrm{SiC}$ (black curve) for annealing condition of $\mathrm{T}=2000^{\circ} \mathrm{C}, \mathrm{P}=300 \mathrm{mbar}$ and an $\mathrm{Al}_{4} \mathrm{C}_{3}-\mathrm{SiC}$ mixture with a composition of $X_{A l 4 C 3}=0.2$ for two different annealing conditions: $T=2000^{\circ} \mathrm{C}, P=300 \mathrm{mbar}$ (blue curve) and $T=1900^{\circ} \mathrm{C}, P=150 \mathrm{mbar}$ (red curve). (b) Thickness of the deposited layer as function of annealing time for these two different experiment conditions with $\mathrm{Al}_{4} \mathrm{C}_{3}-\mathrm{SiC}$ mixture are also presented.

\subsubsection{Deposit on the $\mathrm{SiC}$ substrate}

Figure 8(b) shows the evolution of the deposit thickness as a function of time for two different annealing conditions. By fixing the deposition temperature at $1900^{\circ} \mathrm{C}$, the deposition rate is $30 \mu \mathrm{m} / \mathrm{h}$ for a pressure of 300 mbar. When the pressure decreases to 150 mbar, the deposition rate increases only slightly to $37 \mu \mathrm{m} / \mathrm{h}$. Otherwise, by increasing the baking temperature to $2000^{\circ} \mathrm{C}$ and keeping the pressure at $300 \mathrm{mbar}$, the deposition rate increases dramatically from 30 to $75 \mu \mathrm{m} / \mathrm{h}$. This comparison demonstrates that in such condition the deposition rate is much more temperature dependent than pressure dependent. The error bars added to the plots are standard deviation of the thickness values. They have been calculated from a statistically relevant number of measurements along the deposit diameter. It is thus kind of tracer of the evolution of the deposit roughness at a macroscopic scale. Clearly, such roughness increases first with the film thickness, but also with the deposition rate.

Figure 9 presents the XRD diagram of the deposits, corresponding to the different points in Figure 8. At $2000^{\circ} \mathrm{C}, 300 \mathrm{mbar}$ and after $20 \mathrm{~min}$, the deposit consists of $\mathrm{Al}_{4} \mathrm{SiC}_{4}$ with a preferred $\{0001\}$ orientation. After $1 \mathrm{~h}, \mathrm{Al}_{4} \mathrm{C}_{3}$ peaks start to appear in the deposit with the same orientation $\{0001\}$. After 2 hours, $\mathrm{Al}_{4} \mathrm{SiC}_{4}$ and $\mathrm{Al}_{4} \mathrm{C}_{3}$ are both present in the deposit and the diffractogram is similar to that of a poly-crystal, i.e. without any specific orientation. Note that for the experiments at 20 minutes and 1 
hour, some very small peaks, identified as belonging to $\mathrm{Al}$ and Si appear. By observing the surface of these deposits by SEM, it was found some microscopic solidified droplets. Energy dispersive X-ray spectroscopy (EDS) analysis demonstrated that those droplets were composed of Al-Si alloys. Due to their location (only at the deposit surface) and their composition, we think that these solidified droplets only formed from the vapor during the cooling down and will not be discussed hereafter. Due to the smaller deposition rate, the experiments at $1900^{\circ} \mathrm{C}$ and 150 mbar were performed for longer time. From 2 to 6 hours, the deposit only consists of $\mathrm{Al}_{4} \mathrm{SiC}_{4}$. After 2 hours, the $\mathrm{Al}_{4} \mathrm{SiC}_{4}$ layer clearly shows a preferred orientation, the $\{0001\}$ which is the one of the $\mathrm{SiC}$ substrate. For longer times, even if the $\{0001\}$ family peaks keep the strongest intensities, some other orientations develop.
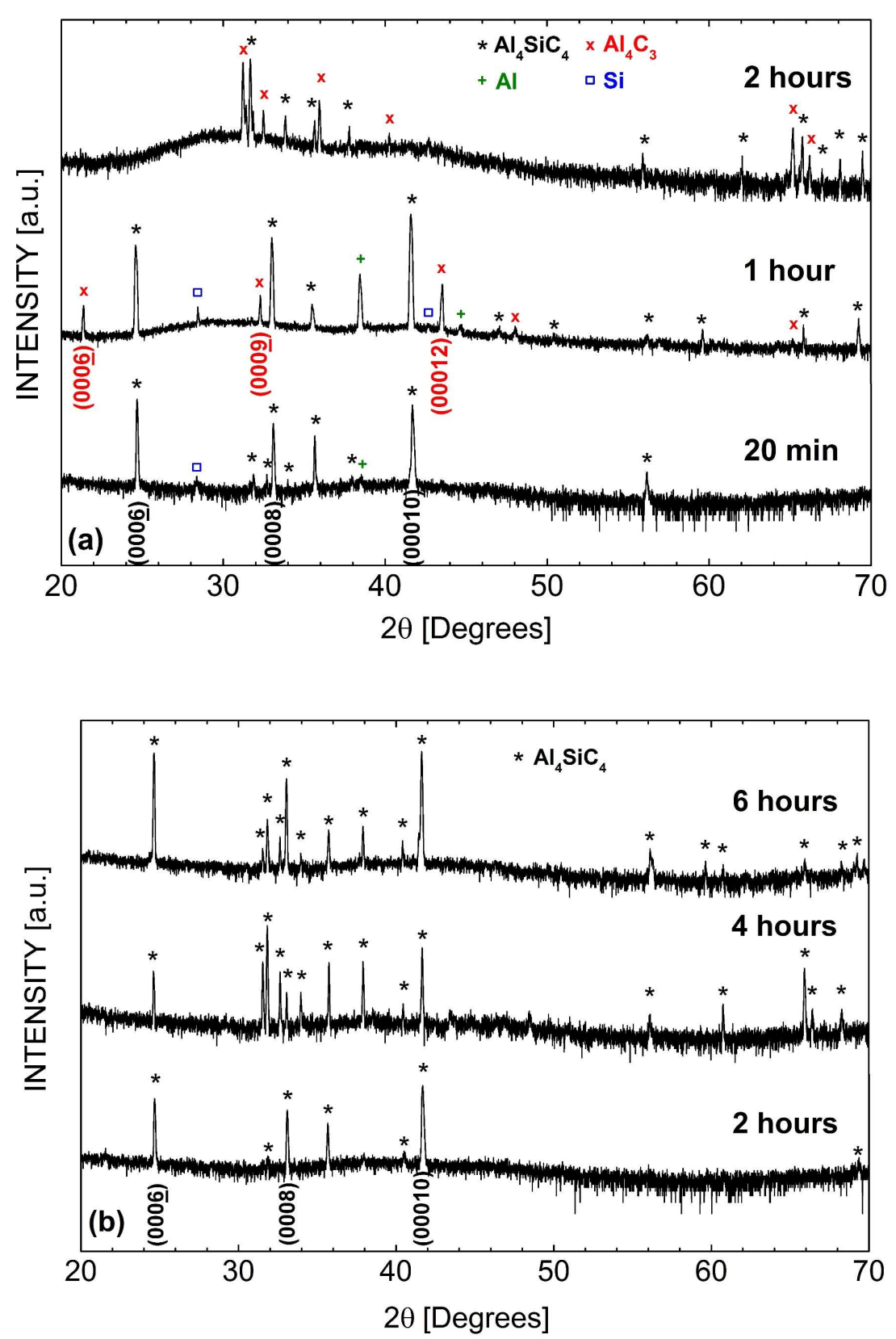

Figure 9: X-ray diffractograms collected from the deposited layers on 4H-SiC substrates after annealing at a) $2000^{\circ} \mathrm{C}$ and $300 \mathrm{mbar}$ and b) $1900^{\circ} \mathrm{C}$ and $150 \mathrm{mbar}$ during different time. The diffraction peaks have been indexed as follows: (*) $\mathrm{Al}_{4} \mathrm{SiC}_{4},(x) \mathrm{Al}_{4} \mathrm{C}_{3}$, (口) $\mathrm{Si}$, (+) Al. The preferred orientation found in the layers are also indicated. 


\subsubsection{Discussion}

In order to compare with the raw composition, the molar fraction of the three elements $(\mathrm{Al}, \mathrm{Si}, \mathrm{C})$ have been extracted from the Rietveld analyses of the powders, only for the medium layers. The results, obtained for different times and the two annealing conditions investigated in this work are gathered in Table 4 . At $1900^{\circ} \mathrm{C}$, the elemental composition of the source was roughly constant even for long baking times, i.e. 6 hours. At $2000^{\circ} \mathrm{C}$, the medium layer showed an enrichment in $\mathrm{Al}$ of about $10 \%$ during the first hour. Then for longer times, the composition progressively shifted back to the initial one.

To draw an accurate picture of the vaporization-condensation phenomena in the $\mathrm{Al}_{4} \mathrm{C}_{3}-\mathrm{SiC}$ system, it is necessary to combine the thermochemistry of the system together with the mass transport occurring in the crucible. For that, we have to differentiate what occurs within the powder, i.e. the formation of the different strata, to what happens in the open cavity above the powder. As demonstrated in section 3.2.2, the effect of pressure in the investigated range is very small, though not negligible, compared with the effect of temperature. It will thus not be discussed any longer.

At a given temperature, the vaporization rate of pure $\mathrm{SiC}$ is constant over the investigated time. Even if the mechanism is a non-congruent vaporization, it states that the flux of $\mathrm{Si}$ is constant. It is rather different for $\mathrm{Al}_{4} \mathrm{C}_{3}$. The vaporization rate of the $\mathrm{Al}_{4} \mathrm{C}_{3}-\mathrm{SiC}$ mixture is extremely strong at the beginning and progressively reaches a saturation. Indeed, there is not $\mathrm{Al}_{4} \mathrm{C}_{3}$ left after any annealing times investigated. According to the phase diagram, with an initial mixture having a composition $\mathrm{X}_{\mathrm{A} 14 \mathrm{C} 3}=0.2$, the equilibrium state should belong to the $\mathrm{Al}_{4} \mathrm{SiC}_{4}-\mathrm{SiC}$ two-phase equilibrium. As the reaction rate between $\mathrm{Al}_{4} \mathrm{C}_{3}$ and $\mathrm{SiC}$ is rather slow (see ref. [2]), we can speculate that a part of it has directly vaporized, producing this initial high vaporization rate. Furthermore, $\mathrm{Al}_{4} \mathrm{C}_{3}$ being a non-congruent melting compound, it produces some graphite upon vaporization. This is what we have experimentally observed. Once all $\mathrm{Al}_{4} \mathrm{C}_{3}$ is consumed, the vaporization rate decreases and then is governed by the $\mathrm{Al}_{4} \mathrm{SiC}_{4}-\mathrm{SiC}$ equilibrium.

At $1900^{\circ} \mathrm{C}$, even if the bottom of the powder starts to graphitize (Figure 7(h)), the $\mathrm{Al}, \mathrm{Si}, \mathrm{C}$ elemental composition of the medium layer (Figure $7(\mathrm{~g})$ ) is almost constant up to $6 \mathrm{~h}$ of annealing. There is no $\mathrm{Al}_{4} \mathrm{SiC}_{4}$ layer forming at the top of the powder. Differently said, the source material facing the seed keeps the same atomic composition, which belongs to the initial pseudo-binary section. As a consequence, stable conditions for the condensation of $\mathrm{Al}_{4} \mathrm{SiC}_{4}$ on the $\mathrm{SiC}$ substrate are fulfilled, over all the deposition time.

At $2000^{\circ} \mathrm{C}$, the evolution is rather different. The huge flux of species coming from the bottom layer (3) leads to a strong enrichment of the medium layer with Al. Progressively, a crust of $\mathrm{Al}_{4} \mathrm{SiC}_{4}$ platelets (layer 1) also develops on the powder surface. Before the formation of this crust, vaporization is fixed by the $\mathrm{Al}_{4} \mathrm{SiC}_{4}-\mathrm{SiC}$ two-phase equilibrium. Similarly to what has been observed at $1900^{\circ} \mathrm{C}$, such case provides proper conditions for the condensation of $\mathrm{Al}_{4} \mathrm{SiC}_{4}$ on the $\mathrm{SiC}$ substrate. However, when the crust of $\mathrm{Al}_{4} \mathrm{SiC}_{4}$ is formed, the surface "emitting" the flux of species to the seed is a pure $\mathrm{Al}_{4} \mathrm{SiC}_{4}$ one. From a thermodynamic point of view, this is associated to an increase of the Al activity and a decrease of the Si activity in the gas phase (see Figure 3). In other words, the gas phase composition experiences an increase of the $\mathrm{Al} / \mathrm{Si}$ and $\mathrm{C} / \mathrm{Si}$ ratios. The $\mathrm{SiC}$ substrate seeing high $\mathrm{Al}$ and $\mathrm{C}$ fluxes compared to the one of $\mathrm{Si}$, it is not surprising to condense $\mathrm{Al}_{4} \mathrm{C}_{3}$ once this situation is reached.

As can be seen from Figures 4 and 5, the condensation of a single $\mathrm{Al}_{4} \mathrm{SiC}_{4}$ phase at the seed area requires a small deviation from thermodynamic equilibrium, i.e. a small temperature difference between the source and the seed, typically lower than $40^{\circ} \mathrm{C}$. Designed with the help of numerical simulation (see Figure 1), the temperature distribution in our crucible perfectly fits this condition. 
Table 4: Molar fraction of the three elements, extracted from the XRD Rietveld analysis of the powder in the medium layer, for different experimental conditions.

\begin{tabular}{|c|c|c|c|}
\hline \multirow{2}{*}{ Experimental conditions } & \multicolumn{3}{|c|}{ Mole fraction } \\
\cline { 2 - 4 } & $\mathrm{Al}$ & $\mathrm{Si}$ & $\mathrm{C}$ \\
\hline Initial composition, $\mathrm{X}_{\mathrm{A} 14 \mathrm{C} 3}=0.2$ & 0.27 & 0.27 & 0.46 \\
\hline $2000^{\circ} \mathrm{C}, 300 \mathrm{mbar}, 20 \mathrm{~min}$ & 0.33 & 0.24 & 0.43 \\
\hline $2000^{\circ} \mathrm{C}, 300 \mathrm{mbar}, 60 \mathrm{~min}$ & 0.37 & 0.22 & 0.42 \\
\hline $2000^{\circ} \mathrm{C}, 300 \mathrm{mbar}, 120 \mathrm{~min}$ & 0.29 & 0.26 & 0.45 \\
\hline $1900^{\circ} \mathrm{C}, 150 \mathrm{mbar}, 120 \mathrm{~min}$ & 0.25 & 0.25 & 0.50 \\
\hline $1900^{\circ} \mathrm{C}, 150 \mathrm{mbar}, 240 \mathrm{~min}$ & 0.29 & 0.23 & 0.48 \\
\hline $1900^{\circ} \mathrm{C}, 150 \mathrm{mbar}, 360 \mathrm{~min}$ & 0.24 & 0.28 & 0.48 \\
\hline
\end{tabular}

To get a very rough estimation of the process yield, we compared the vaporized amount to the condensed amount for a given condition, based on the data from Figure 8 . For instance, at $2000^{\circ} \mathrm{C}, 300$ mbar and after $120 \mathrm{~min}$, the vaporized amounts of $\mathrm{SiC}$ and $\mathrm{Al}_{4} \mathrm{C}_{3}$ are of $5.10^{-4} \mathrm{~mol}$ and $127.10^{-4} \mathrm{~mol}$, respectively. The condensed amount of $\mathrm{Al}_{4} \mathrm{SiC}_{4}$ on the $\mathrm{SiC}$ substrate is about $2.6 .10^{-4}$ mol. Thus, about $50 \%$ of the vaporized $\mathrm{SiC}$ contributes to the deposit, but only $2 \%$ of the vaporized $\mathrm{Al}_{4} \mathrm{C}_{3}$. This estimation is only indicative as the vaporization of these two carbide is not congruent. But it shows a good agreement with the "thermodynamic contribution" of the different species, calculated in Figure 6 . The vaporization of $\mathrm{Al}_{4} \mathrm{C}_{3}$ produces a large excess of $\mathrm{Al}_{(\mathrm{g})}$ that almost does not contribute to the deposit.

\section{Conclusion}

In order to propose a possible $\mathrm{Al}_{4} \mathrm{SiC}_{4}$ single crystal growth process from the vapor phase, we investigated in this paper vaporization and condensation phenomena starting from $\mathrm{Al}_{4} \mathrm{C}_{3}$ and $\mathrm{SiC}$ mixtures. From thermodynamic calculations and a set of experiments, we could derive the following constraints on its implementation: i) a SiC-rich initial composition $\left(\mathrm{X}_{\mathrm{Al} 4 \mathrm{C} 3}<0.5\right)$ of the source materials, ii) a small temperature gradient between the source and the seed to avoid condensation of parasitic phases, iii) moderated mass transport to avoid strong evolutions of the system and again, the condensation of parasitic phases. According to these conditions, a bulk growth process based on the seeded sublimation method is unlikely to produce $\mathrm{Al}_{4} \mathrm{SiC}_{4}$ ingots at a high rate. However, this method has been successfully applied for the growth of high quality, thick A14SiC4 deposits, and thus constitutes a good basis for its synthesis. Deposition on $4 \mathrm{H}-\mathrm{SiC}$ single crystalline substrates could be further explored to control epitaxial growth.

\section{Acknowledgements}

Author would like to thanks Dr. Elisabeth Blanquet for her help on Factsage, Dr. Odette Chaix-Pluchery for her help on Raman characterization, Hervé Roussel for his help on XRD characterization.

\section{References}

1. Barczak VJ (1961) Optical and X-Ray Powder Diffraction Data for A14SiC4. Journal of the American Ceramic Society 44:299-299. https://doi.org/10.1111/j.1151-2916.1961.tb15383.x

2. Schoennahl J, Willer B, Daire M (1984) The mixed carbide Al4SiC4 - preparation and structural data. Journal of Solid State Chemistry 52:163-173. https://doi.org/10.1016/0022-4596(84)901877 
3. Inoue K, Yamaguchi A (2003) Synthesis of Al4SiC4. Journal of the American Ceramic Society 86:1028-1030. https://doi.org/10.1111/j.1151-2916.2003.tb03414.x

4. Lee J-S, Lee S-H, Nishimura T, Tanaka H (2009) Hexagonal Plate-like Ternary Carbide Particulates Synthesized by a Carbothermal Reduction Process: Processing Parameters and Synthesis Mechanism. Journal of the American Ceramic Society 92:1030-1035. https://doi.org/10.1111/j.1551-2916.2009.03056.x

5. Huang XX, Wen GW, Cheng XM, Zhang BY (2007) Oxidation behavior of Al4SiC4 ceramic up to $1700^{\circ}$ C. Corrosion Science 49:2059-2070. https://doi.org/10.1016/j.corsci.2006.10.028

6. Huang X x, Wen G w (2007) Mechanical properties of A14SiC4 bulk ceramics produced by solid state reaction. Ceramics International 33:453-458. https://doi.org/10.1016/j.ceramint.2005.10.009

7. Wen GW, Huang XX (2006) Increased high temperature strength and oxidation resistance of A14SiC4 ceramics. Journal of the European Ceramic Society 26:1281-1286. https://doi.org/10.1016/j.jeurceramsoc.2004.12.032

8. Yamaguchi A, Zhang S (1995) Synthesis and Some Properties of $\mathrm{Al}_{4} \mathrm{SiC}_{4}$. J Ceram Soc Japan 103:20-24. https://doi.org/10.2109/jcersj.103.20

9. Hussain A, Aryal S, Rulis P, et al (2008) Density functional calculations of the electronic structure and optical properties of the ternary carbides A14SiC4 and Al4Si2C5. Physical Review B 78:. https://doi.org/10.1103/PhysRevB.78.195102

10. Zevgitis D, Chaix-Pluchery O, Doisneau B, et al (2015) Synthesis and characterization of $\mathrm{Al}_{4} \mathrm{SiC}_{4}$ : A "new" wide band gap semiconductor material. pp 974-977

11. Pedesseau L, Even J, Modreanu M, et al (2015) $\mathrm{Al}_{4} \mathrm{SiC}_{4}$ wurtzite crystal: structural, optoelectronic, elastic, and piezoelectric properties. Apl Materials 3:121101. https://doi.org/10.1063/1.4936667

12. Kimoto T, Cooper JA (2014) Fundamentals of Silicon Carbide Technology: Growth, Characterization, Devices and Applications. John Wiley \& Sons Singapore Pte. Ltd

13. Chaussende D, Wellmann PJ, Pons M (2007) Status of SiC bulk growth processes. Journal of Physics D 40:6150-6158. https://doi.org/10.1088/0022-3727/40/20/S02

14. Gröbner J, Lukas HL, Aldinger F (1996) Thermodynamic calculation of the ternary system Al-SiC. Calphad 20:247-254. https://doi.org/10.1016/s0364-5916(96)00027-2

15. Oden L, McCune RA (1987) Phase equilibria in the Al-Si-C system. Metallurgical Transactions A (Physical Metallurgy and Materials Science) 18A:2005-2014. https://doi.org/10.1007/BF02647073

16. Ariyawong K, Chatillon C, Blanquet E, et al (2016) A first step toward bridging silicon carbide crystal properties and physical chemistry of crystal growth. CrystEngComm 18:2119-2124. https://doi.org/10.1039/c5ce02480c

17. Ma RH, Zhang H, Ha S, Skowronski M (2003) Integrated process modeling and experimental validation of silicon carbide sublimation growth. Journal of Crystal Growth 252:523-537. https://doi.org/10.1016/s0022-0248(03)00944-8

18. Madar R, Pons M, Dedulle JM, et al (2000) Numerical Simulation of SiC Boule Growth by Sublimation. Materials Science Forum 338-342:25-30. https://doi.org/10.4028/www.scientific.net/MSF.338-342.25

19. Moulin C, Pons M, Pisch A, et al (2001) SiC Single Crystal Growth by Sublimation: Experimental and Numerical Results. MSF 353-356:7-10. https://doi.org/10.4028/www.scientific.net/MSF.353-356.7 